\title{
Assuring of Learning Goals System Implementation as a Catalyst of School of Economics and Business Sarajevo Quality Upgrading
}

\author{
Elvir Čizmić ${ }^{*}$ Kenan Crnkić \\ School of Economics and Business Sarajevo, Sarajevo University, Trg oslobođenja - Alija Izetbegović 1, 71000 Sarajevo, \\ Bosnia-Herzegovina \\ *Corresponding Author: elvir.cizmic@efsa.unsa.ba
}

Copyright (C) 2013 Horizon Research Publishing All rights reserved.

\begin{abstract}
The main goal of this paper is to present the Double Closing Quality Loop Model and assuring of learning tools and data that could be used to obtain continuity in quality development of higher education institutions in sense of learning outcome achieving and assurance of learning considering all main stakeholder requirements. Model is created to assure internal and external monitoring of improvements of core higher education institution processes. This integral procedure is aimed to obtain sufficient and solid decision making platform for higher education institution management and inform other stakeholders to ensure continuous modifications and improvements of academic programs quality and assurance of learning process.
\end{abstract}

Keywords International Accreditation Standards, the Double Closing Quality Loop Model, Assurance of Learning Goals (AOL), Decision Making

\section{Introduction to Higher Education Institutions Contemporary Situation}

To be competitive in today's business conditions means continuously implement innovative changes in the management of business operations with the aim of improving internal and external quality of organization as a whole. Apply appropriate principles of contemporary concepts of management and entrepreneurship within the higher educational institutions is a "condition sine qua non", and without them there is no their quality development within contemporary postindustrial context. (Wissema, 2010) Their application has to be adjusted to the humans, principles, processes and activities that are immanent to the higher education institutions. Context of innovative flexible adaptation should be understood in terms of the principles of strategic entrepreneurship and total quality management application on each governing and operational process within higher educational institutions. (Kyrö \& Mattila, 2010) Using the principles of strategic entrepreneurship higher education institutions will be able to deliver value to all stakeholders in an effective way, while the application of the total quality management principles will ensure delivery of the specified value in an efficient way, which provides a managerial balance which guarantees long-term institutional business success.

It means that within contemporary ages and future business context, management of higher education institutions will have to obtain high level of managerial knowledge, capabilities and competences in accordance to use modern managerial concepts and tools. External and internal factors will generate some pressures on higher education institutions governing bodies and academic staff to be more and more qualified and capable to attract more and more sensitive educational industry clients and retain institutional quality status within teaching, researching and consulting activities. (Prince \& Beaver, 2008) It means that high ranking universities, faculties and schools have to develop advanced general and specific procedure created to assure internal and external monitoring of improvements higher education institution core and support processes. (Bengt \& Lövingsson, 2005) The processes of teaching and learning have to be adjusted now and in the future considering to the different stakeholders' requirements and interests and management of higher education institutions have to obtain balance in fulfilling of them. (Biggs, 2001) In order to understand quality model of higher education institution it is necessary to scrutinize main content elements of this specific quality model. All these models are underpinned by the fundamental management theory and total quality management in general, but still there are some specific aspects that have to be involved in tractate about quality management within higher education institutions. According that management and academic and administrative staff could be asking themselves a lot of very 
important questions such as what is a university, what does it mean to be educated, who will be educated and by whom, who guarantees the quality of the offerings of an institution, how are faculty members involved in the governance of the institution and how is academic freedom guaranteed? (Buck, 2001) Considering that questions the main international accreditations institutions for higher education organizations prescribe some standards that have to be fulfilled, if some higher education institution wants to be accredited. Benchmarks or standards for assessing institutional visions, missions and goals, leadership and management, staffing, resource provision, courses, teaching and learning, support for faculty and students, assessment, learning outcomes and internal quality assurance provide helpful frameworks for institutions and auditors but, however, there may never be a single definitive or universally accepted set of criteria for quality measurement within different models, ways and types of education. (Jung \& Latchem, 2007)

The procedure of earning some accreditation certificate is very complicated and exhausted, but that procedures push management of higher education institution to upgrade higher institution quality continuously from year to year.

\section{Higher Education Institution Accreditation Standards and Procedures}

Accreditation is a process of external quality review created and used by higher education to scrutinize colleges, universities and programs for quality assurance and quality improvement. (Eaton, 2012) There are two most important and prestigious accreditation institutions for higher education institution devoted to teaching business and economy and they are AACSB-the Association to Advance Collegiate Schools of Business and EFMD-European Foundation for Management Development. AACSB International-The Association to Advance Collegiate Schools of Business advances quality management education worldwide through accreditation, thought leadership, and value-added services. Through its accreditation standards and processes, AACSB recognizes institutions that uphold its mission and core values, work to advance the interests of global management education, and participate in AACSB's community of leading business schools. In this context, AACSB focuses on continuous quality improvement in management education through innovation, impact, and engagement. EFMD plays a central role in shaping an international approach to management education and is a unique forum for information, research, networking and debate on innovation and best practice in management development. EFMD provides an international platform to bring together leaders in the management education profession, and membership brings many opportunities for partnerships, student and faculty exchanges and the sharing of knowledge and ideas. There are only about 57 higher education institutions within area of business and economy that have earned both of these accreditation institutions certificates, and those higher education institutions are considered as the best in the world between them about 13000 worldwide. This relations and number are changing from year to year and if we take in consideration the third accreditation house AMBA (AMBA-Association of MBAs is the international impartial authority on postgraduate business education) in consideration the higher institutions that earned all three certificate have the Triple Crown and their worldwide number is even double less. All these accreditations institutions prescribe some requirements about higher education institution quality and the way of fulfilled those requirements of earning accreditation certificate. Some of the main requirements or standards that are defined by these institutions begin from the general managerial aspects that are connected to the mission statement and institution development strategy to the issues that are bind to the intellectual contributions, student mission, admission and retention procedures, financial issues, human resources issues, educational responsibility, learning goals, etc. Within the continues of this paper it will be presented how School of Economics and Business Sarajevo-SEBS progressing in their efforts to achieve AACSB accreditation by analyzing its upgrading by developing new assurance of learning goals system. Some general steps of getting accreditation certificate could be presented through the scheme that follows (Figure 1).

As Figure 1 shoves, this general framework procedure can be longer or shorter and it depends of higher institution management and staff competences and capacity, but all institutions, that wish to earn accreditation certificate, have to pass similar procedures. That general procedure includes preparation of institutional Action Plan-AP, Standard Alignment Plan-SAP, Self Estimation Report-SER, and at list two Progress Report-PR, that will be following up by the mentor and different types of comities and teams such as Preaccreditations Comity-PAC, Initial Accreditation Comity-IAC, Accounting Accreditation Comity-AAC, Pear Review Team-PRT, etc. SEBS has defined orientation to earning the most prestigious accreditations in its vision and mission statement and defined some goals according that within its strategic map (Čizmić, Šunje, Trivun, 2011) as some guiding tool in its endeavors (Figure 2).

\section{General Methodological Model for Assurance of Learning Goals of SEBS Programs}

Based on projected SEBS strategy map it has been introduced an advanced general methodological model for assurance of learning goals-AOL. Through conducting a pilot undergraduate program in academic 2011/2012 SEBS management has proposed certain improvements of the 
Closing the loop process that had earlier been used. Although the process had been assessed as feasible and solid for B\&H cultural context and resources available, it was upgraded with specified stakeholders that are introduced at the end of the process along with the corrective and preventive measures.

As Figures 3 shoves, Assurance of Learning Goals procedure uses the Double Closing Quality Loop on SEBS (Argyris, 1999) that is created to obtain internal and external monitoring of SEBS processes improvements. The first loop is internal oriented and directed to collect and analyses all Assurance of Learning Goals data in sense of teaching quality, students' contentment and students' achievements during program attending. The second loop is external oriented and directed to obtain SEBS management all information about graduated students' achievement within their careers, employability rate, employees contentment and their current work positions in their employers' organizations and in this case for data collecting is charged SEBS Centre for Student Career Development. As main variables, in this model, are considering the employees contentment and the employability rate, as the dependent variables which present external quality. The teachers' quality average grade and student's contentment and achievement average rate are considered as independent variables which present internal quality. It means that independent variables are defined with the quality of the programs, teachers and students, while dependent variables are defined with the external stakeholders' quality perception. According to the previous experience, pilot programs and long period of monitoring different kind of SEBS processes and activities has been obviously noticed prudence trends and alignment of these variables through positive correlation between them in sense that during upgrading internal quality activities and processes there is almost instant growth of external quality in sense of different external stakeholders' perception rate. It is the main logic of all SEBS activities and processes that have been cause-effect settled in sense of enforcement of main strategic actions and that logic of continual quality improving processes could be considered as the main factor for SEBS study programs potential candidate enrolment decision. This integral model is adjusted and modified according to the particular categories of students, therefore, the most of SEBS self financed DL students are already employed and SEBS can measure progress in their career in sense of better position in organization or salary range in relationship of students average grades and for that purpose are created special questionnaire/rubrics for data collecting as the building part of integral quality model. This integral procedure is aimed to obtain satisfactory decision making platform for SEBS management and other responsible instances within SEBS to make decisions about program modification and improvements by upgrading of higher education institution programs quality and planning some changes in program and procedure to upgrade capacity of all graduates.

\begin{tabular}{|c|c|c|c|c|c|c|}
\hline \multicolumn{5}{|c|}{ PREACCREDITATION PROCESS } & \multicolumn{2}{|c|}{ INITIAL ACCREDITATION PROCESS } \\
\hline$\underline{\mathrm{YEAR}} 1$ & YEAR 2 & $\underline{\text { YEAR } 3}$ & $\underline{\mathrm{YEAR}} 4$ & $\underline{\text { YEAR } 5}$ & YEAR 6 & YEAR 7 \\
\hline $\begin{array}{l}\text { - Applicant submits } \\
\text { Eligibility } \\
\text { Application }\end{array}$ & $\begin{array}{l}\text { - If necessary, Mentor } \\
\text { conducts another on- } \\
\text { site visit }\end{array}$ & $\begin{array}{l}\text { - Once AP is } \\
\text { accepted, Mentor } \\
\text { conducts annual on- } \\
\text { site visit to assist } \\
\text { applicant in AP } \\
\text { implementation }\end{array}$ & $\begin{array}{l}\text { - If necessary, Mentor } \\
\text { conducts annual on- } \\
\text { site visit to assist } \\
\text { applicant in AP } \\
\text { implementation }\end{array}$ & $\begin{array}{l}\text { - If necessary, Mentor } \\
\text { conducts annual on- } \\
\text { site visit to assist } \\
\text { applicant in AP } \\
\text { implementation }\end{array}$ & $\begin{array}{l}\text { - Applicant submits } \\
\text { letter of application } \\
\text { for initial } \\
\text { accreditation. }\end{array}$ & $\begin{array}{l}\text { - Applicant submits } \\
\text { SER to PRT \& IAC } \\
\text { (or AAC) for review }\end{array}$ \\
\hline $\begin{array}{l}\text { - Application is } \\
\text { reviewed by PAC }\end{array}$ & $\begin{array}{l}\text { - Applicant continues } \\
\text { to develop AP \& } \\
\text { SWOT analysis }\end{array}$ & $\begin{array}{l}\text { - Applicant submits } \\
\text { progress report }\end{array}$ & $\begin{array}{l}\text { - Applicant submits } \\
\text { progress report }\end{array}$ & $\begin{array}{l}\text { - Applicant submits } \\
\text { progress report }\end{array}$ & $\begin{array}{l}\text { - PRT Chair is } \\
\text { appointed and } \\
\text { assumes monitoring } \\
\text { responsibility from } \\
\text { Mentor. }\end{array}$ & $\begin{array}{l}\text { - PRT reviews SER \& } \\
\text { drafts previsit letter, } \\
\text { confirming the PRT } \\
\text { on-site review }\end{array}$ \\
\hline $\begin{array}{l}\text { - If application is } \\
\text { accepted, Mentor is } \\
\text { appointed }\end{array}$ & $\begin{array}{l}\text { - Mentor provides } \\
\text { update to PAC } \\
\text { liaison on } \\
\text { applicant's progress } \\
\text { toward AP } \\
\text { completion }\end{array}$ & $\begin{array}{l}\text { - Mentor provides } \\
\text { update to IAC (or } \\
\text { AAC) on applicant's } \\
\text { progress report }\end{array}$ & $\begin{array}{l}\text { - Mentor provides } \\
\text { update to IAC (or } \\
\text { AAC) on applicant's } \\
\text { progress report }\end{array}$ & $\begin{array}{l}\text { - Mentor provides } \\
\text { update to IAC (or } \\
\text { AAC) on applicant's } \\
\text { progress report }\end{array}$ & $\begin{array}{l}\text { - Remaining PRT } \\
\text { members are } \\
\text { appointed }\end{array}$ & $\begin{array}{l}\text { - IAC (or AAC) } \\
\text { reviews the previsit } \\
\text { letter \& PRT } \\
\text { recommendation for } \\
\text { concurrence }\end{array}$ \\
\hline $\begin{array}{l}\text { - Mentor establishes } \\
\text { contact with } \\
\text { applicant }\end{array}$ & $\begin{array}{l}\text { When completed, } \\
\text { applicant submits } \\
\text { AP to PAC for } \\
\text { review }\end{array}$ & $\begin{array}{l}\text { - IAC (or AAC) } \\
\text { corresponds with } \\
\text { applicant on } \\
\text { progress and/or } \\
\text { concerns }\end{array}$ & $\begin{array}{l}\text { - IAC (or AAC) } \\
\text { corresponds with } \\
\text { applicant on } \\
\text { progress and/or } \\
\text { concerns }\end{array}$ & $\begin{array}{l}\text { - IAC (or AAC) } \\
\text { corresponds with } \\
\text { applicant on } \\
\text { progress and/or } \\
\text { concerns }\end{array}$ & $\begin{array}{l}\text { - PRT Chair conducts } \\
\text { on-site visit to } \\
\text { consult w/applicant } \\
\text { in preparation of } \\
\text { SER }\end{array}$ & $\begin{array}{l}\text { - Once concurrence is } \\
\text { reached, PRT visit } \\
\text { occurs as scheduled }\end{array}$ \\
\hline $\begin{array}{l}\text { - Mentor conducts on- } \\
\text { site visit to identify } \\
\text { \& resolve eligibility } \\
\text { issues }\end{array}$ & $\begin{array}{l}\text { - Mentor reviews } \\
\text { plan \& provides } \\
\text { recommendation to } \\
\text { PAC }\end{array}$ & & & $\begin{array}{l}\text { - If applicant has made } \\
\text { satisfactory progress, } \\
\text { IAC (or AAC) } \\
\text { directs applicant to } \\
\text { apply for initial } \\
\text { accreditation process }\end{array}$ & $\begin{array}{l}\text {-Visit dates for PRT } \\
\text { review are } \\
\text { established }\end{array}$ & $\begin{array}{l}\text { - Within } 10 \text { days of } \\
\text { visit, PRT Chair } \\
\text { distributes Team } \\
\text { Report to applicant } \\
\text { \& IAC (or AAC) }\end{array}$ \\
\hline $\begin{array}{l}\text { - Within } 10 \text { days of } \\
\text { visit, Mentor submits } \\
\text { report to PAC } \\
\text { containing } \\
\text { recommendation on } \\
\text { eligibility issues, } \\
\text { highlighting areas of } \\
\text { concern \& indicating } \\
\text { timetable for AP } \\
\text { completion }\end{array}$ & $\begin{array}{l}\text { - PAC reviews AP \& } \\
\text { can: (1) accept AP } \\
\& \text { forward plan } \\
\text { along w/ confirmed } \\
\text { eligibility criteria to } \\
\text { IAC (or AAC) for } \\
\text { review or (2) request } \\
\text { further revision \& } \\
\text { resubmission of AP }\end{array}$ & & & & $\begin{array}{l}\text { - Applicant works to } \\
\text { complete SER and } \\
\text { refine SP }\end{array}$ & $\begin{array}{l}\text { - Applicant provides } \\
\text { PRT \& IAC (or } \\
\text { AAC) response to } \\
\text { Team Visit Report } \\
\text { (OPTIONAL) }\end{array}$ \\
\hline
\end{tabular}

Figure 1. General framework procedure for AACSB accreditation 


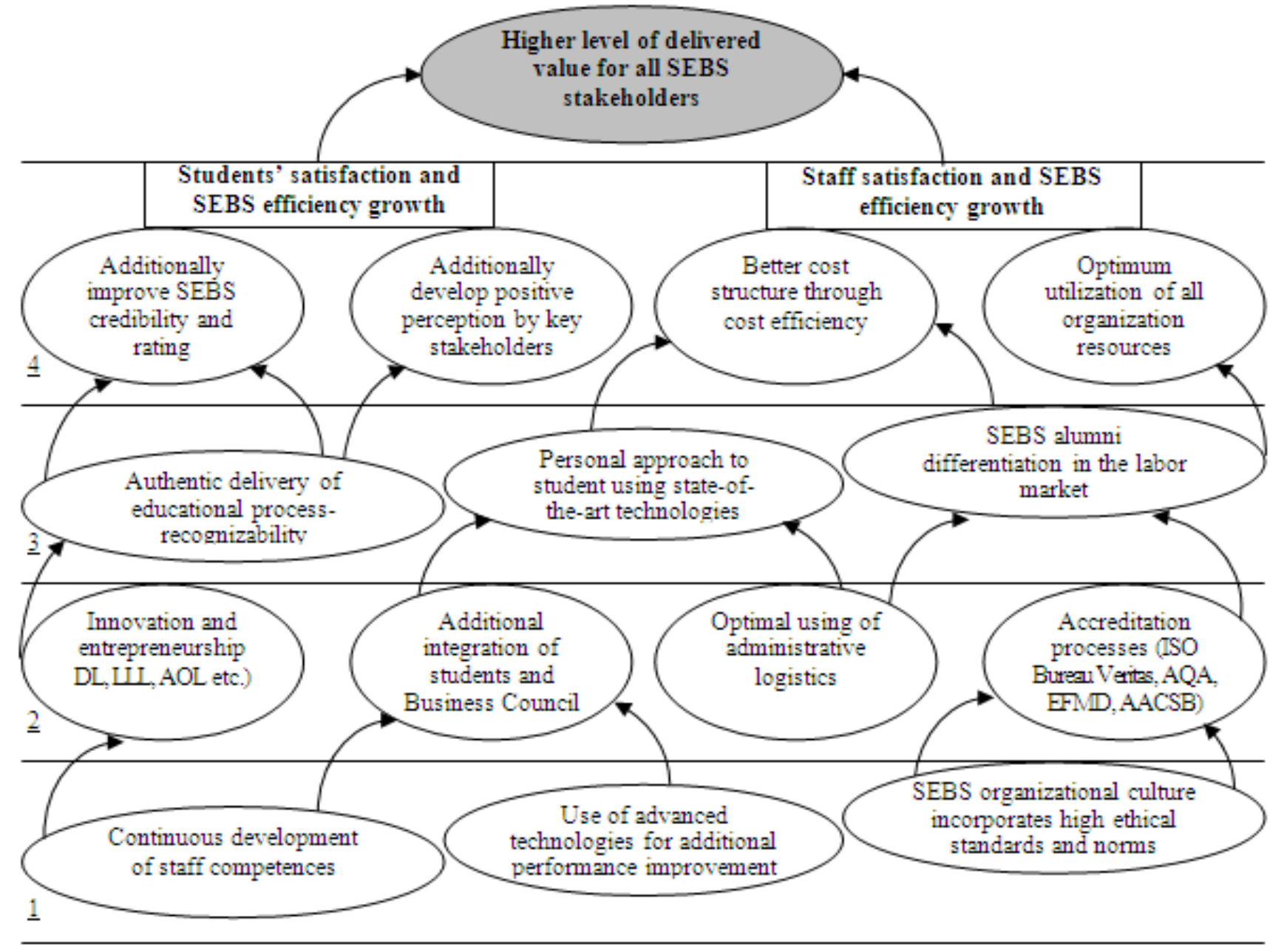

Figure 2. Projection of School of Economics and Business Sarajevo strategic map 


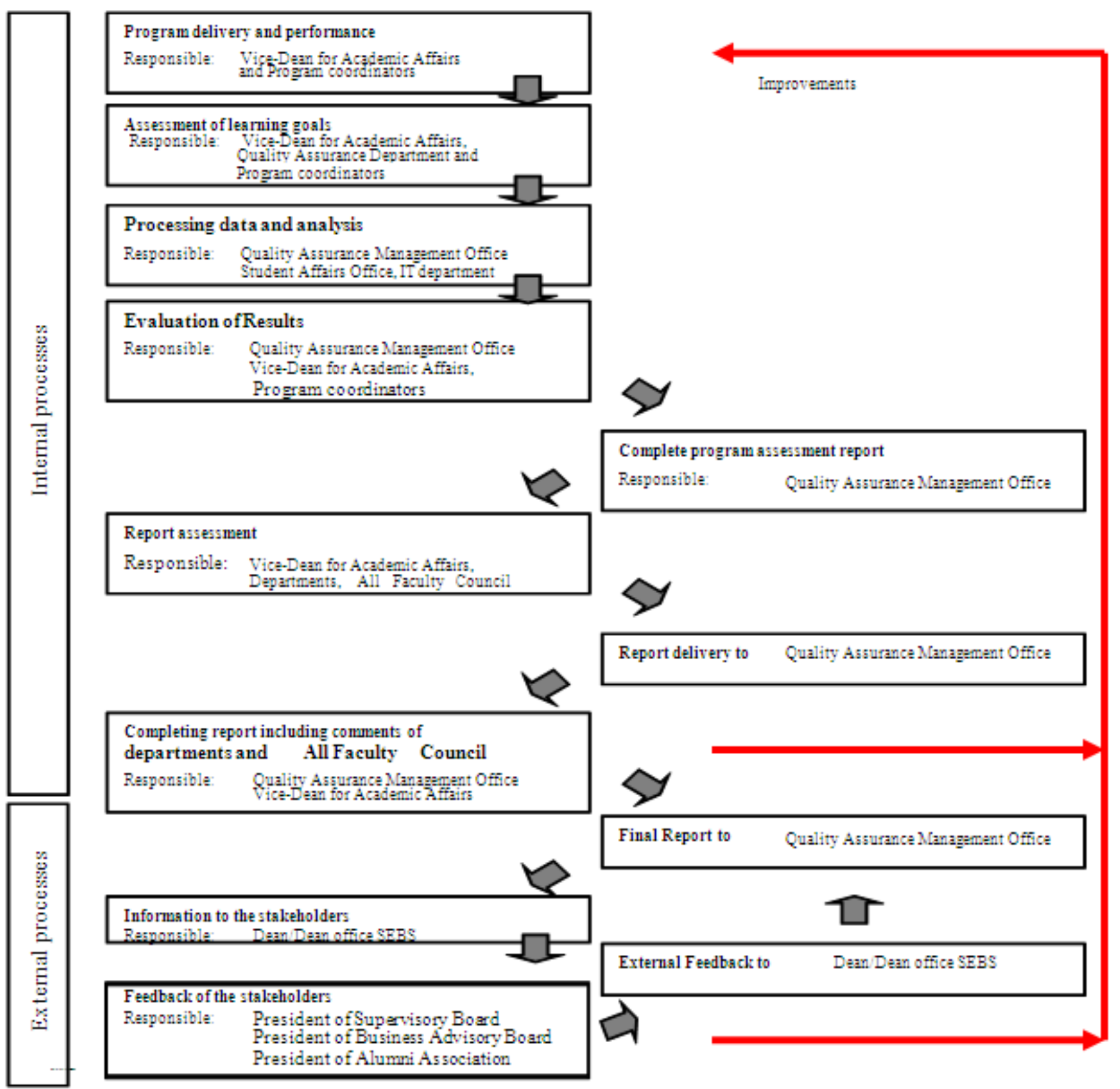

Figure 3. Assurance of Learning Goals - the Double Closing the Quality Loop at SEBS

SEBS now uses an advanced general procedure under the heading Double Closing Quality Loop procedure, which has been authentically created in order to assure internal and external monitoring of improvements of SEBS's AOL processes and consequently upgrades program quality and capabilities in process of students' career development. In sense of upgrading and introduction of adequate achievement of learning goals measurement system for bachelor, master and doctoral programs according to Bologna principles, SEBS has developed special structured questionnaires/rubrics. For the first cycle study programs this system has introduced before three years and after that it has been, using adaptive "roll out" procedure, translate to the master and doctoral programs and it will be used for evaluation of learning outcomes for all SEBS's programs. For purpose of this SEBS has developed very sophisticated tools for following up quality of all its programs that will be used for data collecting and upon that managerial decision making. Considering the fact of SEBS previous monitoring experience of different processes and activities, SEBS technical capacity for frequent analyze more than fifty percent of any students categories and according to the central limit theorem requirement and random sampling process, there is assumption of normal distribution for variables of this model. In order to set up the management and coordination procedures within the assessment process, SEBS will use new general procedure for data analysis, reporting activities, dissemination of results, accepting feedback suggestion and undertake corrective and preventive actions through evaluation of project, master and doctoral thesis for all master and doctoral 
programs.

In the context of redefining the School of Economics and Business Sarajevo assurance of learning system according to the Double Closing Quality Loop, besides other aspects directed to developing the culture of strategically focused learning organization, the main goal is to develop the School of Economics and Business Sarajevo adequate monitoring mechanism. The Double Closing Quality Loop is a graphical representation of critical monitoring system through simple and easily understandable positions, elements and activities. The Double Closing Quality Loop model as such is a precious and useful communication tool within the organization, which gives signals to all stakeholders associated with a given organization using different type of questionnaires/rubrics which are authentically developed for any activity that is subject of measurement, monitoring and controlling. By means of this procedure, the organization presents way of how it wants to achieve within their core activities in the future period, in a simple, easily understandable and coherent way. The Double Closing Quality Loop is developed through team work, and is not separated from operational, daily work requirements on the spot.

\section{SEBS Assurance of Learning Goals System Functioning}

At SEBS monitoring and evaluating of undergraduate AOL had started as a pilot project in academic year 2011/2012. Academic program in Management, with two streams of Financial Management and Marketing Management (completely held in English), have been used as a pilot sample. The main aim of this pilot project was to obtain results and experience needed for additional development of the AOL process that would improve introduction of AOL system for all undergraduate, master and doctoral programs within SEBS, starting from academic 2012/2013.

For measuring learning goals presented in the Table 1, SEBS developed and introduced structured questionnaires/rubrics for evaluation of undergraduate diploma paper, international project and internship. All statements in the questionnaires are graded using 5-point Likert scale, where 1 stands for "absolutely disagree", while 5 is" absolutely agree with the statement". SEBS goal was to reach average result per learning goals of more than 3.5.

All pre-developed questionnaires/rubrics were collected by the Students Affairs Office and processed by IT department using scanning hardware and specialized software. A data analysis was subsequently completed by the Quality Assurance Management Office. Results have been analyzed for different assessment methods individually and will be presented in a condensed form. As it can be seen from Table 2, all learning goals assessed through undergraduate diploma paper have reached above the minimum that had been originally defined as 3.5. The best evaluated learning goal is "Communication", with average grade of 4.538 , but it could be notice some progress in two consecutive period comparisons within the table.

In addition, undergraduate learning goals were assessed through international project and it was apparent that grades are lower as compared to results obtained from undergraduate diploma papers evaluation, but still above the minimum threshold of 3.5. A possible explanation may be seen in the way a defense of the undergraduate diploma paper is carried out, since it is, by default, understood as the final exam and it is open for public evaluation of students' work. That is why students invest additional effort in order to fulfill their own expectations, but also those of their parents. "Knowledge" is best evaluated learning goal in this assessment with an average grade of 3.60, but SEBS started special project that are aimed to assure better results in this field including SEBS International Office activities ,some internal seminars, courses and training to involve and encourage students to be part of real international projects. In the similar way the pilot project also included the assessment of undergraduate learning goals through internship and the results within this has been very good with average grade of 4,75. All these procedures and activities are ongoing process and they became regular and standard procedures within with total quality management SEBS system with pretensions to transfer similar model to all cycles and program study from 2012/2013 academic year.

In terms of development and introduction of adequate measurement of achievement of learning goals for Master programs SEBS has developed specially structured surveys that will be used for evaluation of Master theses for all SEBS's Master programs until the end of 2013. Particularly designed questionnaires that SEBS has developed for the Second Cycle of study (Specialized Master's degree programs) that will be used for data collecting are authentically developed for this purpose. In order to set up the management and coordination procedures within the assessment process, SEBS will use general procedure called the Double Closing the Quality Loop system, as explained before.

The Master programs have not been assessed yet. Structured questionnaires have been duly developed and are in use starting from academic year 2012/2013. By the end of year 2013 the assessment system for Master programs will be fully functional. The responsibility for implementation of the measurement system rests with the program coordinators, Vice Dean for Academic Affairs together with Quality Assurance Management Office, also supported with the Student Affairs Office and IT department. The Quality Assurance Management Office (in coordination with the Vice-Dean for Academic Affairs) is responsible for development of assessment tools, monitoring and coordination of the process of assessment, analysis and reporting, as well as of providing suggestions for eventual corrective and preventive measures.

The programs will be evaluated once a year. The data collected will be assessed by the Master Project Questionnaire/Rubrics (Master Project Questionnaire is given in Appendix 1) at the end of the first year, and also by 
Master Theses Questionnaire/Rubrics that is shown in Appendix 2. The results will be collected by the Student Affairs Office and processed by IT department using specialized hardware and software. A thorough analysis of data will be done every semester by the Quality Assurance Management Office and this unit is obliged to produce standard report with recommendations for upgrading system and especially quality of the programs.

For purpose of developing system for Assurance of Learning Goals management of SEBS has developed specific questionnaires/rubrics that will be used for following up of quality and learning goals fulfillment by the students for all cycles of the study and all programs. For example Table 3 presents an overview of general and specific learning goals and ways of their assessment for the specialized master's degrees.

For first cycle of the study this system is introduced within SEBS earlier through pilot project, but the master programs have not been assessed yet because these questionnaires/rubrics just have been put into practice this spring and the first analyzes and decisions based on them are expected this autumn. An example of these tools is master project questionnaire/rubrics that has bilingually created (BiH and English language) and it uses segment of measurement that has represented within Table 3 .

Table 1. SEBS undergraduate's programs (3 years)

\begin{tabular}{|c|c|c|c|}
\hline \multirow[t]{2}{*}{ LEARNING GOALS } & \multicolumn{3}{|c|}{ ASSESSMENT } \\
\hline & $\begin{array}{l}\text { Diploma } \\
\text { paper }\end{array}$ & $\begin{array}{l}\text { International } \\
\text { project }\end{array}$ & Internship \\
\hline Knowledge & & & \\
\hline $\begin{array}{l}\text { General knowledge: } \\
\text { All undergraduates will be familiar with and able to understand the global context of business, } \\
\text { the major markets and trends. }\end{array}$ & + & + & + \\
\hline $\begin{array}{l}\text { Specific Knowledge: } \\
\text { - Academic Program in Economics: Students will be able to apply basic principles of } \\
\text { economics in macro economical environment } \\
\text { - Academic Program in Management: Students will be able to apply business concepts and } \\
\text { best practices in a global environment } \\
\text { - Applied Business: Students will be able to apply specific knowledge in regular business } \\
\text { activities. } \\
\text { - Sarajevo Business School: Students will be able to define and use the key concepts of } \\
\text { business and modern management practices. }\end{array}$ & + & + & + \\
\hline $\begin{array}{l}\text { Thinking skills } \\
\text { Graduates will be able to evaluate critically professional situations and solve problems in } \\
\text { international business context. }\end{array}$ & + & + & + \\
\hline $\begin{array}{l}\text { IT skills } \\
\text { Graduates will be able to conduct basic data analysis on specific business and academic issues, } \\
\text { using IT technology. }\end{array}$ & + & + & + \\
\hline $\begin{array}{l}\text { Communication skills } \\
\text { Graduates will be able to communicate effectively with different stakeholders while respecting } \\
\text { different cultures and business practices in the international environment. }\end{array}$ & + & + & + \\
\hline $\begin{array}{l}\text { Ethics, social responsibility and international perspective } \\
\text { Graduates will be able to understand ethical principles in business behavior, and to understand } \\
\text { the dimensions of (international) business. }\end{array}$ & + & + & + \\
\hline
\end{tabular}


Assuring of Learning Goals System Implementation as a Catalyst of

School of Economics and Business Sarajevo Quality Upgrading

Table 2. Results of AOL assessment using undergraduate diploma papers

\begin{tabular}{|c|c|c|c|c|c|c|c|c|c|c|c|}
\hline \multirow{2}{*}{\multicolumn{2}{|c|}{ AOL Goals }} & \multicolumn{5}{|c|}{ June-October 2011} & \multicolumn{5}{|c|}{ June-October 2012} \\
\hline & & \multirow[t]{2}{*}{$\mathbf{N}$} & \multirow[t]{2}{*}{ Min } & \multirow[t]{2}{*}{$\operatorname{Max}$} & \multirow{2}{*}{$\begin{array}{c}\text { Average } \\
4.423\end{array}$} & \multirow[t]{2}{*}{ St. dev. } & \multirow[t]{2}{*}{$\mathbf{N}$} & \multirow[t]{2}{*}{ Min } & \multirow[t]{2}{*}{$\operatorname{Max}$} & \multirow{2}{*}{$\begin{array}{c}\text { Average } \\
4.55\end{array}$} & \multirow[t]{2}{*}{ St. dev } \\
\hline 1. & Knowledge & & & & & & & & & & \\
\hline \multicolumn{2}{|r|}{ 1.1. General Knowledge } & & & & 4.415 & & & & & 4.56 & \\
\hline 1.1.1. & Student understands the main concepts of business and management. & 211 & 3 & 5 & 4.55 & 0.562 & 384 & 1 & 5 & 4.62 & 0.58 \\
\hline 1.1.2. & Student understands corporate interactions in South - East Europe. & 155 & 3 & 5 & 4.26 & 0.593 & 367 & 1 & 5 & 4.48 & 0.63 \\
\hline 1.1.3. & Student is able to conduct a qualitative and quantitative analysis of data. & 178 & 3 & 5 & 4.39 & 0.612 & 371 & 2 & 5 & 4.59 & 0.58 \\
\hline \multicolumn{2}{|r|}{ 1.2. Specific Knowledge } & & & & 4.434 & & & & & 4.53 & \\
\hline 1.2.1. & Student is able to evaluate particular theories against empirical findings. & 182 & 3 & 5 & 4.38 & 0.570 & 372 & 1 & 5 & 4.56 & 0.63 \\
\hline 1.2.2. & Student is able to implement specific knowledge in business practice. & 191 & 3 & 5 & 4.49 & 0.551 & 380 & 1 & 5 & 4.51 & 0.61 \\
\hline 2. & Thinking skills & & & & 4.343 & & & & & 4.49 & \\
\hline 2.1. & Student is able to define a consistent research plan. & 206 & 2 & 5 & 4.36 & 0.646 & 390 & 3 & 5 & 4.49 & 0.59 \\
\hline 2.2 . & $\begin{array}{l}\begin{array}{l}\text { Student is able to critically evaluate particular academic research published in an } \\
\text { academic article. }\end{array} \\
\end{array}$ & 210 & 3 & 5 & 4.26 & 0.685 & 389 & 2 & 5 & 4.45 & 0.63 \\
\hline 2.3 . & Student is able to analyze professional situations and identify problems. & 310 & 2 & 5 & 4.41 & 0.645 & 379 & 2 & 5 & 4.54 & 0.59 \\
\hline 3. & IT skills & & & & 4.433 & & & & & 4.56 & \\
\hline 3.1 . & $\begin{array}{l}\begin{array}{l}\text { Student is able to use on-line databases in order to conduct research on a specific } \\
\text { issue. }\end{array} \\
\end{array}$ & 198 & 3 & 5 & 4.48 & 0.602 & 389 & 1 & 5 & 4.56 & 0.63 \\
\hline 3.2 . & $\begin{array}{c}\begin{array}{c}\text { Student is able to use basic computer programs in order to conduct a quantitative } \\
\text { research on a specific issue. }\end{array} \\
\end{array}$ & 190 & 3 & 5 & 4.41 & 0.659 & 381 & 2 & 5 & 4.57 & 0.61 \\
\hline 4. & Communication skills & & & & 4.538 & & & & & 4.56 & \\
\hline 4.1. & Student is able to develop a professional presentation and deliver it individually. & 210 & 3 & 5 & 4.61 & 0.603 & 387 & 2 & 5 & 4.59 & 0.56 \\
\hline 4.2. & $\begin{array}{l}\begin{array}{l}\text { Student is able to communicate effectively with different stakeholders in case studies and/or } \\
\text { practical problem solving. }\end{array} \\
\end{array}$ & 184 & 3 & 5 & 4.46 & 0.561 & 372 & 2 & 5 & 4.53 & 0.59 \\
\hline 5. & Ethics, social responsibility and international perspective & & & & 4.534 & & & & & 4.59 & \\
\hline 5.1. & Student understands and applies ethical principles in business behavior. & 174 & 2 & 5 & 4.66 & 0.595 & 375 & 1 & 5 & 4.58 & 0.58 \\
\hline 5.2 . & $\begin{array}{l}\begin{array}{l}\text { Student understands and promotes the importance of new concepts of economic } \\
\text { development. }\end{array} \\
\end{array}$ & 170 & 3 & 5 & 4.41 & 0.611 & 371 & 1 & 5 & 4.58 & 0.61 \\
\hline 5.3. & $\begin{array}{c}\text { Student understands the importance of the international perspective of social } \\
\text { corporate responsibility. }\end{array}$ & 156 & 3 & 5 & 4.53 & 0.584 & 356 & 1 & 5 & 4.61 & 0.58 \\
\hline
\end{tabular}


Table 3. SEBS Master's programs ( 1 and 2 years)

\begin{tabular}{|c|c|c|}
\hline LEARNING GOALS & \multicolumn{2}{|c|}{ ASSESSMENT } \\
\hline GENERAL & $\begin{array}{l}\text { Project } \\
\text { I year }\end{array}$ & $\begin{array}{c}\text { Master thesis } \\
\text { II year }\end{array}$ \\
\hline $\begin{array}{c}\text { General Cognitive Knowledge } \\
\begin{array}{c}\text { Graduates will have a full insight into main economic theories, and understand and apply main } \\
\text { managerial concepts, laws and regulations of business, major markets and trends. }\end{array}\end{array}$ & + & 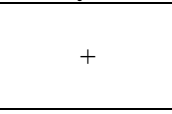 \\
\hline $\begin{array}{c}\text { Logic and Reasoning } \\
\begin{array}{c}\text { Graduates will be able to critically evaluate statements and terms adequately based on logic and } \\
\text { reasoning and offer problem solutions. }\end{array}\end{array}$ & + & + \\
\hline $\begin{array}{c}\text { Conceptual Knowledge } \\
\text { Graduates will be able to infer logical conclusions and give comprehensive recommendations based on } \\
\text { new and novel business concepts application. }\end{array}$ & + & + \\
\hline $\begin{array}{c}\text { Researching Potential and Skills } \\
\text { Graduates will be able to define a logic researching hypotheses based on cause effect relationship and } \\
\text { infer logical researching conclusions. }\end{array}$ & + & + \\
\hline $\begin{array}{l}\text { Emotional Intelligence and Cross-cultural issues } \\
\text { Graduates will be able to perform effectively individually or in teams, including leadership, } \\
\text { teambuilding, presenting, motivating and international social and researching networking. }\end{array}$ & + & + \\
\hline $\begin{array}{l}\text { Ethics and social responsibility } \\
\text { Graduates will be able to apply and promote principles of ethical behavior, environmental sensitivity } \\
\text { and social responsibility in business environments. }\end{array}$ & + & + \\
\hline SPECIFIC & & \\
\hline $\begin{array}{l}\text { Descriptive note for any stream individually noted by the mentor/committee/coordinator } \\
\text { Mentor will descriptively define main areas, activities and project that graduates can successfully } \\
\text { perform in their future work engagements and evaluate some specific issues. }\end{array}$ & + & + \\
\hline
\end{tabular}

The master programs will be evaluated once a year in a way that two years programs will be assessed by authentically developed the Master Project questionnaire at the end of the first year and by Master Theses Questionnaire/Rubrics at the end of the second year of master program. All the questionnaires are collected by the Students Affairs Office and processed by IT department using specialized software and scanner. A thorough analysis of data will be done every semester by the Quality Assurance Management Office and the management of SEBS will generate some decisions and instructions for programs and system of learning assurance upgrading. (Devenport, 2006) Master Project Questionnaire/Rubrics is according practical projects oriented and composed of six main parts according to the Table 3. The first five segment of rubrics are created in general for all types of SEBS master programs, while the sixth part is created to obtain some specific information that are different for each particularly SEBS program. The first part is intended to obtain information about general knowledge and skills of the students and their capabilities of logic reasoning according to the general project management framework, the second one is oriented to get information about students capabilities of diagnose some problems and their solving in a novel way and the third part is oriented to investigate students capabilities for recognizing and supposing some strategic cause effect relations projects. The fourth general part is intended to scrutinize students understanding of project team working issues and the fifth one is oriented to search some ethics issues according to the defining and implementation of the different projects. The sixth specifically created part is intended to obtain information about students' capabilities to apply project management principles within specific scientific and business fields and their skills of project assignments performing within specific fields in international context. This document will be filled by Master Thesis Mentor and transfer to Students Affairs Office and processed by IT department.

Master Theses Questionnaire/Rubrics is more scientific oriented and composed of six main parts according to the Table 3. The first five parts of rubrics are created in general for all types of SEBS master programs, while the sixth part is created to obtain some specific information that are different and special for each particularly SEBS program. The first part is intended to obtain information about general cognitive knowledge for fully understanding and harnessing of the different theoretical business and economics concepts and their capabilities for creating novel concepts through system logical reasoning, the second one is oriented to get information about students capabilities for critically evaluated and redefined particular theoretical concepts and their business application, while the third part is directed to investigate students capabilities for establishing researching hypotheses and issues. The fourth general part is intended to scrutinize students' emotional intelligence and cross-cultural potential in sense of their capabilities in knowledge dissemination and international scientific network understanding and harnessing, while the fifth one is oriented 
to search some ethics and corporate responsibilities issues understanding. The sixth specifically created part is intended to obtain information about students' capabilities to apply project management principles within specific scientific and business fields and their skills of project assignments performing within specific fields in international context. Master Theses Questionnaire/rubrics will be filled by All Committee Members.

Structured questionnaires/rubrics (for final Master thesis), are developed and will be in use starting from academic year 2012/2013. By the end of year 2013 the assessment system for master programs will be fully functional. A questionnaire/rubric is a scoring or grading tool that helps create a certain level of objectivity. As a result, teachers and learners are clearer about the expectations prior to submitting the assignment and are clear about their areas of weakness and strength when the assignment is returned. Rubrics help mentors evaluate levels of performance and communicate with students without the need to write extensive comments on an assignment. Using these tools in a systematic way helps to the directors of the programs and school management to make decisions for upgrading quality of the program making them more flexible and adjustable according to the business community requirements. The responsibility for implementation of the measurement system rests with the program coordinators, Vice Dean for Academic Affairs and Quality Assurance Management Office, who are supported with the Students Affairs Office and IT department. The Quality Assurance Management Office (in coordination with the Vice-Dean for academic affairs) is responsible for using developed assessment tools, monitoring and coordination of the process of assessment, analysis and reporting, as well as suggestion of corrective and preventive measures. Similar questionnaire/rubrics are developed for SEBS doctoral (PhD and DBA) programs and they will be part of this system for assurance of learning goals, also. The data collected in this way will obtain for SEBS management to make extra ordinate decisions that will generate upgrading of institutional education quality from semester to semester.

Considering above SEBS will continue invest endeavors and money to the process of encouraging and strengthening academic capacity of their academic staff in context of creation better curricula, achieving better learning outcome and as a consequence better status of SEBS students within labor market in sense of employability rate and their carrier progress. Accordingly, SEBS will obtain activities that will generate attracting best applicants for all study cycles and all forms of education, increasing degree of internalization, income growth with cost optimization, teaching process proceeding in accordance with international accreditation standards, proactive curricula innovations in accordance with needs and requirements by business practice and labor market and optimization of functioning of all administration support processes.

\section{Conclusion}

All SEBS organizational units which including more that fifteen academic and administrative organizational units, centers and services which are precisely designed to work compatible in activities of SEBS strategic aims implementation. Accordingly, SEBS management and staff will continue with endeavor of fulfillment accreditation requirements because that systematically led improvement process upgrades quality of higher education institution from day to day in all segment of its functioning. SEBS management is well aware of these facts and international and global trends posting all higher education institution in position to be globally and internationally exposed. It means that process of different type of integrations, including European integration also, will set new requirements in front of higher education institution. Accreditation processes that are conducted within SEBS during the last decade are produced different kind of benefit for this higher education institution in sense of upgrading quality in any segment of its functioning. This strategic orientation will ensure better SEBS core competences that will make platform to build better long run regional competition and recognizable position.

As a consequence of these upgrading processes SEBS has earned some accreditation certificate from very prestigious accreditation institution. In May 2012, SEBS was awarded the EPAS accreditation by the prestigious European Foundation for Management Development (EFMD). SEBS dedication to quality and international accreditation was duly recognized by the EFMD expert team, which accredited two first cycle (undergraduate) programs regularly delivered in English language: „Financial Management" and „Marketing Management". Under specific conditions EPAS accreditation was awarded for the three years period.

SEBS is also the only higher education institution in Bosnia and Herzegovina that is accredited by Austrian Agency for Quality Assurance (AQA) for the maximum period of six years. AQA representatives will pay control visits to SEBS every year during this period, so during last two years SEBS undertook a huge number of activities in aim to improve its quality. Before about three moths AQA Peer Review Team has visited SEBS and checked all its process and activities and after that process SEBS is confirmed its accredited status again.

SEBS is in its way to bee accredited by very prestigious AACSB accreditation and invests a lot of effort in that process. SEBS has passed some stages in this very intensive process and during the last four years SEBS developed its SAP-standard Alignment Plan that was accepted by the AACSB committee, create the first PR-Progress Report that was accepted, too. The next step is to create the second PR and after that SEBS is obliged to make its self progress report and expecting visit by the AACSB Peer Review Team. SEBS is fully dedicated to this process with main goal, not only to get accreditation certificate, but to upgrading its overall organizational quality from day to day, from year to year and 
as a consequence to earn AACSB accreditation.

\section{REFERENCES}

[1] Argyris, Chris, (1999): On Organizational Learning, Second edition, Blackwell Publishing, 1999. pg. 68-69.

[2] Bengt, Karlöf, Lövingsson H. Fredrik, (2005): The A-Z of Management Concepts and Models, British Library, pg. 389.

[3] Davenport, H., Thomas, (2006): Thinking for a Living-How to Get Better Performance and Results from Knowledge Workers, Harvard Business School Press, pg. 10-14.

[4] Elvir Čizmić, Aziz Šunje, Veljko Trivun, (2011): Managerial Process Upgrading Through Balanced Scorecard Concept Application - Case of School of Economics and Business Sarajevo, University of Split, Faculty of Economics Conference Proceedings, pg. 83.

[5] Insung Jung, Colin Latchem, (2007), Assuring Quality in Asian Open and Distance Learning, Open Learning Consultant Australia, International Christian University, Japan, Vol. 22, No. 3, pg. 237.
[6] Jane Buck, (2001): Assuring Quality in Distance Education, Higher Education in Europe, Vol. XXVI, No. 4, pg. 600.

[7] John Biggs, (2001): The Reflective Institution: Assuring and Enhancing the Quality of Teaching and Learning, Kluwer Academic Publisher, Adapted, pg. 222.

[8] Judith S. Eaton; (2012): An Overview of U.S. Accreditation; Council for Higher Education Accreditation; pg. 3.

[9] Kyrő, Paula; Mattila, Johanna; (2010): Towards future University by Integrating Entrepreneurial and the Third Generation University Concepts; pg. 4-5.

[10] Prince Cristopher, Beaver graham; (2008): The Rise of The Corporate University-The Emerging Corporate Learning Agenda; The international Journal of Management Education, pg. 22.

[11] Wissema J. G.: (2010): Leading the Third Generation University-Towards a comprehensive management theory of the $3 \mathrm{GU}$; pg. 44-45.

[12] http://www.aacsb.edu/accreditation/business/standards/2013/ 2013-business-standards.pdf; (30. Jul. 2013)

[13] http://www.efmd.org/images/stories/efmd/downloadables/EF MD/efmd-bout_efmd_update $\% 202013$ online_ne w.pdf; (30. Jul. 2013) 